\title{
Ad ornatum templorum loci Pere erant. Ewakuacja dzieł sztuki z łacińskich kościołów Pery po 1453 roku
}

\section{Abstract \\ Ad ornatum templorum loci Pere erant. Evacuation of the Works of Art from the Latin Churches of Pera after 1453}

Pera-a Genoese colony located on the north shore of the Golden Horn was seized by the Ottoman Turks in 1453, that is at the same time when Constantinople fell. There were numerous Latin churches there at that time, 18 of which we can list by names. Significant parts of two of them have survived, namely of the Dominican church of St. Paul and a Benedictine one. The Genoese almost immediately began to evacuate the elements of the decorations of the Latin churches. This took place usually at the initiative of the families of the original donors and the maintainers of Pera monastic churches. At least partially, it was the result of the papal bull issued by Nicholas V on 8 October 1453, in which the Pope called the clergy and laity, under penalty of excommunication, to save objects and liturgical books from Turkish hands. However, it pointed out that they should return to Pera if the Christians regain control over the colony. One example of such activity was the transfer of items from the church of Santa Chiara in Pera to St. Dominic's church in Genoa that was carried out in early 1456 by Marietta di Pagana, who came directly from Pera. Another one took place at the same time when descendants of Tommaso Spinola, a wealthy Genoese merchant, donated liturgical vestments to the same church that Tommaso originally founded for the Dominicans in Pera. Dominicans themselves 
evacuated relics and the most valuable elements of the church equipment to Chios and later to Genoa, while a similar attempt made by the Benedictines failed.

In unknown circumstances, however, a much larger number of items from the churches of Pera arrived on the Genoese island of Chios and from there, in early 1461, were transported to Genoa. On 23 January 1461, the Genoese Signoria authorized six officiales from the finest families to carry out a large-scale operation to transfer the items, including many relics and books, to the churches of the metropolis. The authorities of Genoa asked Pope Pius II for help in conducting this project. Consequently, more than 20 churches of Genoa received valuable fittings. What is particularly important, donations to individual churches needed to be documented in an appropriate detailed inventory, including the estimated value of individual objects. Unfortunately, these documents did not record any information about specific churches from which the items originally came. They enable us to reconstruct the course of this action, and partly characterize the works of art that were brought to Genoa. They thus provide us with partial knowledge about the character of the equipment of the Pera churches. A few of them are still in Genoa. It is worth noting that this transport was preceded by a number of other works of art from the East that reached the Ligurian metropolis even as early as in the $13^{\text {th }}$ century. This action was also one of the major shipments of works of art into the Latin West, which occurred immediately after the fall of the capital of the Eastern Empire in 1453.

Keywords: Pera (Genoese colony), Constantinople, Genoa, Latin churches, Ottoman conquests, icons, reliquaries

\section{Kościoły łacińskie Pery i jej zajęcie przez Osmanów}

Genueńska kolonia Pera (il. 1) funkcjonowała na północnym brzegu Złotego Rogu od 1267 roku' ${ }^{1}$ Już we wczesnym okresie jej rozwoju (1267-1304) pojawiły się tam pierwsze kościoły łacińskie, wśród

1 Zob. G.I. Brătianu, Recherches sur le commerce génois dans la mer Noire au XIIIe siècle, Paris 1929, s. 89-90; J. Sauvaget, Notes sur la colonie génoise de Péra, „Syria. Revue d'art oriental et d'archéologie” 15 (1934), s. 252-253; M. Balard, La Romanie génoise (XII - début du XVe siècle), Genova-Rome 1978 („Atti della Società Ligure di Storia Patria", nuova serie 18 (92). Bibliothèque des Écoles Françaises d'Athènes et de Rome, fasc. 135), s. 182. 
których znajdowały się świątynie pod wezwaniem: św. Heleny (z hospicjum), św. Michała, św. Franciszka (franciszkański), Matki Bożej, św. Ireny oraz powstały zapewne w pobliżu tej ostatniej świątyni kościół św. Pawła (dominikański) ${ }^{2}$. Niektóre z nich, zwłaszcza w początkowym okresie istnienia placówki genueńskiej, były zaadaptowanymi na potrzeby łacinników dawnymi świątyniami bizantyńskimi. W ciągu XIV wieku i pierwszej połowy XV ich liczba znacznie się powiększyła, tak że w chwili zajęcia Pery przez Turków w jej murach znajdowało się co najmniej osiemnaście świątyń katolickich. Do największych należały: tak zwana katedra św. Michała, kościół św. Franciszka wraz z mniejszym - św. Anny, należące do franciszkanów, oraz wspomniany kościół dominikański św. Pawła (nazywany też św. Dominika). Ponadto w Perze funkcjonowały kościoły: Santa Maria della Misericordia della Cisterna (kościół Benedyktynów), Matki Boskiej (Santa Maria Draperis?), kościół z hospicjum św. Antoniego, św. Klary, św. Katarzyny (kościół Dominikanek), św. św. Piotra i Pawła oraz klasztor Braci Mniejszych (obserwantów), zapewne również z kościołem, dalej kościoły św. Fabiana, św. Ireny, św. Jerzego, św. Jana Chrzciciela, św. Klemensa, św. Mikołaja oraz św. Sebastiana ${ }^{3}$. Istnienia kolejnych kościołów można się domyślać między innymi na podstawie występujących w źródłach nazw dzielnic -

2 Zob. J. Sauvaget, Notes sur la colonie..., s. 255-256; M. Balard, La Romanie génoise..., s. 182-183.

3 Zob. E. Dalleggio D’Alessio, Recherches sur l'histoire de la Latinité de Constantinople. II: Nomenclature des églises latines de Galata, „Echos d'Orient” 25 (1926), s. 24-38; R. Janin, La géographie ecclésiastique de l'empire byzantin. La siege de Constantinople et le patriarcat oecuménique, t. III: Les églises et le monastéres, Paris 1969, s. 584-593; M. Balard, La Romanie génoise..., s. 195-196; S. Eyice, Testimonianze genovesi in Turchia, „Il Veltro. Rivistà della Civiltà Italiana” 23 (marzo-agosto 1979), no. 2-4 (Le relazioni tra l'Italia e la Turchia), s. 66-68; S.S. Darnault, Latin Catholic Buildings in Istanbul. A Historical Perspective (18391923), Istanbul 2004, s. 61-75; C. Barsanti, Il panorama di Cristoforo Buondelmonti e le chiese latine di Costantinopoli, w: Domenicani a Costantinopoli prima e dopo l'impero ottomano. Storia, immagini e documenti d'archivio, a cura di C. Monge, S. Pedone, Firenze 2017 (Biblioteca di Memorie Domenicane, 17), s. 62-67. 
contrade, które, podobnie jak w Genui, pochodziły z reguły od wezwań znajdujących się na ich terenie kościołów ${ }^{4}$.

Do dziś zachowały się jedynie znaczne fragmenty dwóch z tych budowli, w tym największego kościoła Pery, którym była zapewne dominikańska świątynia św. Pawła (św. Dominika) o wymiarach $47 \times 15 \mathrm{~m}$, powstała w pierwszej ćwierci XIV wieku (pomiędzy 1299 a 1323 rokiem). Ceglano-kamienny kościół (dziś meczet Arap Camii) posiadał pierwotnie zapewne niesklepioną pojedynczą nawę, z wydzielonym chórem zakonnym, zakończoną od wschodu kwadratowym prezbiterium $\mathrm{z}$ dwiema kwadratowymi kaplicami po bokach (il. 2). Przy południowo-wschodnim narożniku kościoła wzniesiono dzwonnicę o wyglądzie przypominającym włoskie kampanile ${ }^{5}$. Architektura świątyni przetrwała w pewnej mierze do dnia dzisiejszego wraz z wieloma szczegółami dekoracyjnymi. Należą do

4 Zob. M. Balard, La Romanie génoise..., s. 192. Np. contrada św. Łazarza odnotowana w 1389 roku.

5 Poszczególni autorzy różnią się w datowaniu budowy kościoła oraz znaczeniu dla niej takich wydarzeń jak: założenie klasztoru dominikańskiego w Perze (1299), wydanie aktu delimitacyjnego kolonii genueńskiej (1303), wygnanie dominikanów z Konstantynopola (1307), pożar Pery (1315) oraz data na najstarszej zachowanej płycie grobowej z tego kościoła (1323): J. Sauvaget, Notes sur la colonie..., s. 260 (datuje budowę kościoła na XIV wiek); R.J. Loenertz, Les établissement dominicains de Péra-Constantinople, „Echos d'Orient” 34 (1935), s. 335-336 (po 1299 roku); B. Palazzo, L'Arap Djami ou Eglise Saint-Paul à Galata, Istanbul 1946, s. 56-57, 88 (początek XIV wieku, ale po 1303 roku); W. Müller-Wiener, Bildlexikon zur Topographie Istanbuls. Byzantion-Konstantinupolis-Istanbul bis zum Beginn d. 17 Jh., Tübingen 1977, s. 79 (1325 rok); S. Eyice, Testimonianze genovesi in Turchia..., s. 67 (pierwsza połowa XIV wieku); J. Cramer, S. Düll, Baubeobachtungen an der Arap Camii in Istanbul, „Istanbuler Mitteilungen” 35 (1985), s. 311-313 (po 1315 roku); S. Westphalen, Pittori greci nella chiesa domenicana dei Genovesi a Pera (Arap Camii). Per la genesi di una cultura figurativa levantina nel Trecento, w: Intorno al Sacro Volto. Genova, Bisanzio e il Mediterraneo (secoli XI-XIV), a cura di A.R. Calderoni Masetti, C. Dufour Bozzo, G. Wolf, Venezia 2007 (Collana del Kunsthistorisches Institut in Florenz, 11), s. 51 (pierwsza ćwierć XIV wieku, ale po 1307 roku); N. Melvani, Dominicans in Byzantium and Byzantine Dominicans. Religious Dialog and Cultural Interaction, w: Domenicani a Costantinopoli..., s. 38 (prawdopodobnie początek XIV wieku). 
nich fragmenty płaskorzeźbionej dekoracji architektonicznej oraz ponad 120 płyt epitafijnych przechowywanych od I wojny światowej w stambulskim Muzeum Archeologicznym ${ }^{6}$. Można na nich znaleźć ornamenty bizantyńskie sąsiadujące $\mathrm{z}$ łacińskimi inskrypcjami oraz heraldyką pochodzenia zachodnioeuropejskiego ${ }^{7}$. Podobnie rzecz ma się z odsłanianymi w tym kościele w latach 1999-2012 fragmentami obszernego cyklu malarskiego powstałego zapewne w pierwszej połowie lub około połowy XIV wieku. Mimo dominacji ikonografii oraz cech stylistycznych należących do malarstwa bizantyńskiego doby Paleologów przedstawiono tam również sceny lub elementy pochodzenia zachodnioeuropejskiego, głównie środkowowłoskiego ${ }^{8}$.

6 Wszystkie znane wówczas płyty nagrobne $\mathrm{z}$ tego kościoła opublikował E. Dalleggio D’Alessio, Le pietre sepolcrali di Arap Giami (Antica chiesa di S. Paolo $a$ Galata), „Atti della R. Deputazione di storia patria per la Liguria” 69 (1942), s. 3-168. Co najmniej dwie płyty znajdują się jednak do dziś w posadzce tej świątyni (zob. S. Düll, Unbekannte Denkmäler der Genuesen aus Galata, II, „Istanbuler Mitteilungen" 36 (1986), s. 250-251).

Zob. J. Cramer, S. Düll, Baubeobachtungen an der Arap Camii..., s. 305-311; S. Düll, Byzanz in Galata. Zur Rezeption byzantinischer Ornamente auf genuesischen Denkmälern des 14. Jahrhunderts, „Römische Historische Mitteilungen” 29 (1987), s. 270-274; idem, Les monuments des Génois en Turquie et leurs rapports avec Byzance, w: État et colonisation au Moyen Âge et à la Renaissance, sous la dir. de M. Balard, Lyon 1989, s. 113-128; N. Melvani, Dominicans in Byzantium..., s. 40-44.

8 Zob. S. Westphalen, Pittori greci..., s. 51-62; idem, Die Dominikanerkirche der Genuesen von Pera (Arap Camii). Griechische Maler - Lateinische Auftraggeber, w: Austausch und Inspiration. Kulturkontakt als Impuls architektonischer Innovation, hrsg. von U. Wulff-Rheidt, F. Pirson, Mainz 2008 (Diskussionen zur Archäologischen Bauforschung, 9), s. 276-291; H. Çetinkaya, Arap Camii in Istanbul. Its Architecture and Frescoes, „Anatolia Antiqua. Eski Anadolu” 18 (2010), s. 169-188; idem, Byzantine Masters at the Service of the Catholic Church at Constantinople, „Porphyra” 8 (2011), no. 16 (2. Bisanzio, Venezia e l'Europa in età paleologa), s. 53-65; E. Akyürek, Palaiologoslar Dönemi Konstantinopolisinde Dominiken Duver Resimleri. Galata Arap Camisi (San Domenico Kilisesi) Freskoları / Dominican Painting in Palaiologan Constantinople. The Frescoes of the Arap Camii (Church of S. Domenico) in Galata, w: Kariye Camii Yeniden / The Kariye Camii Reconsidered, ed. by H.A. Klein, R.G. Ousterhout, B. Pitarakis, İstanbul 2011 (İstanbul Araştırmaları Enstitüsü 
Zachowały się ponadto fragmenty znacznie przekształconego kościoła noszącego wezwanie św. Benedykta (St. Benoit). Za czasów genueńskich należał on do założonego tu 12 maja 1427 roku klasztoru Benedyktynów i równolegle nazywany był Santa Maria della Misericordia della Cisterna. Pozostała do dziś kamienna wieża z ceglanymi detalami dekoracyjnymi, zaś do 1958 roku także ostrołukowy portal dziedzińca klasztornego, wsparty na kolumnach. Najprawdopodobniej kościół ten (wraz ze wspomnianą wieżą i portalem) powstał w czasach genueńskich, czyli pomiędzy 1427 a 1453 rokiem?9. Zgodnie z opinią Philippa Niewöhnera benedyktyni przejęli jednak grecki kościół Matki Bożej, powstały około roku 1300, i tak należy datować również oba wzmiankowane wyżej elementy budowli ${ }^{10}$.

Podczas gdy położony po drugiej stronie zatoki Konstantynopol został ostatecznie zdobyty przez Turków osmańskich 29 maja 1453 roku, genueńskie władze Pery następnego dnia poddały ją Mehmedowi II Zdobywcy bez walki, ufając w zawarte nieco wcześniej z tureckim władcą porozumienie, $\mathrm{w}$ myśl którego mieszkańcy magnifica comunità di Pera mieli zachować swą własność osobistą, kościoły i statki. W zamian musieli jedynie uznać władzę zwierzchnią sułtana, opłacać podatki, nie dzwonić dzwonami oraz nie budować nowych świątyń. Już 1 czerwca 1453 roku Mehmed II potwierdził warunki

Yayınları / İstanbul Research Institute Publications, 14), s. 301-326 i 327-341; N. Melvani, Dominicans in Byzantium..., s. 45-47, 49.

9 Zob. E. Dalleggio D’Alessio, Le monastère de Sainte Marie de la Miséricorde de la Citerne de Péra ou de Saint-Benoît. Des origines a l'occupation du monastère par les Jésuites (12 mai 1427-18 novembre 1583), „Echos d'Orient” 33 (1934), s. 63; J. Sauvaget, Notes sur la colonie..., s. 260-261; S. Eyice, Testimonianze genovesi in Turchia..., s. 67; V. Polonio, Santa Maria della Misericordia della Cisterna a Pera di Costantinopoli, w: Italia Benedettina, II: Liguria monastica, Cesena 1979, s. 405; S.S. Darnault, Latin Catholic Buildings in Istanbul..., s. 160, 164; C. Barsanti, Il panorama di Cristoforo Buondelmonti..., s. 63.

10 Zob. P. Niewöhner, Saint Benoît in Galata. Der byzantinische Ursprungsbau, "Jahrbuch des Deutschen Archäologischen Instituts" 124 (2009), s. 216-219, 222-232. 
kapitulacji Pery w specjalnie wydanym dokumencie (ahidname $)^{11}$. Mimo że Pera wciąż zachowała charakter łaciński i miała znaczną liczbę ludności katolickiej, znajdujące się na jej terenie kościoły stopniowo były jednak przekształcane na meczety bądź rozbierane ${ }^{12}$. Na przykład dominikanie zostali usunięci ze swego klasztoru już przed czerwcem 1476 roku, zaś należący do nich kościół św. Pawła zamieniono na meczet Arap Camii około $1480 \mathrm{roku}^{13}$. Choć na początku XVII wieku na terenie Pery funkcjonowało pięć kościołów klasztornych, większość spośród średniowiecznych kościołów łacińskich zostało rozebranych w wiekach XVI i XVII, zwłaszcza w wyniku zniszczeń dokonanych przez kilka pożarów dawnej Pery w XVII wieku ${ }^{14}$.

\section{Ewakuacja wyposażenia kościołów Pery}

Mimo zawartego układu i wydanego na jego podstawie dokumentu kapitulacyjnego (ahidname) Genueńczycy przystąpili jednak do ewakuacji wyposażenia kościelnego ${ }^{15}$. Odbywało się to $\mathrm{z}$ reguły

11 Zob. E. Dalleggio D’Alessio, Traité entre les Génois de Galata et Mehmet II (1 ${ }^{\text {er }}$ juin 1453). Versions et commentaires, „Echos d'Orient” 39 (1940), s. 161-175; V. Polonio, Santa Maria della Misericordia..., s. 412; F. Özden Ercan, The Genoese of Pera in the Fifteenth Century. Draperio and Spinola Families, w: Living in the Ottoman Realm. Empire and Identity, $13^{\text {th }}$ to $20^{\text {th }}$ Centuries, ed. by C. Isom-Verhaaren, K.F. Schull, Bloomington (Ind.) 2016, s. 47-50 (ahidname zostało powtórzone przez sułtana Ahmeda I w 1613 roku).

12 Zob. S.S. Darnault, Latin Catholic Buildings in Istanbul..., s. 33, 61-75.

13 Zob. J. Sauvaget, Notes sur la colonie..., s. 268-272; R.J. Loenertz, Les établissement dominicains..., s. 339.

14 Zob. S.S. Darnault, Latin Catholic Buildings in Istanbul..., s. 35; P. Girardelli, Lo sviluppo urbano e architettonico di Galata nei documenti dell'Archivio domenicano, w: Domenicani a Costantinopoli..., s. 105-109.

15 Podstawowe dokumenty odnoszące się do tej akcji opublikował Luigi Tommaso Belgrano, Prima serie di documenti riguardanti la colonia di Pera, „Atti della Società Ligure di Storia Patria" 13 (1877-1884), s. 274-281; idem, Seconda serie di documenti riguardanti la colonia di Pera, „Atti della Società Ligure di Storia Patria” 
z inicjatywy rodów będących pierwotnie darczyńcami świątyń Pery oraz zakonnych opiekunów poszczególnych kościołów klasztornych. Cenne przedmioty podążały za tą częścią łacińskich mieszkańców Pery, którzy zdecydowali się na emigrację. Wywozili oni zapewne przedmioty o szczególnym dla nich znaczeniu emocjonalnym w celu uniknięcia ich ewentualnej profanacji.

Jednym z przykładów takich działań było przekazanie na początku 1456 roku przez przybyłą bezpośrednio z Pery Mariettę di Pagana, córkę Gasparego, elementów wyposażenia kościoła św. Klary w Perze genueńskiej świątyni San Domenico. Jak się dowiadujemy z dokumentu spisanego w zakrystii przy tym ostatnim kościele w dniu 17 stycznia 1456 roku, Marietta di Pagana ofiarowała przedmioty przez siebie zakupione bądź też osobiście przez nią wykonane. Wobec sytuacji, w której znalazła się Pera, pragnieniem di Pagany stało się, by „pozostały [one] w poświęconym miejscu i służyły kultowi Bożemu" ${ }^{16}$. W przypadku jednak przywrócenia władzy genueńskiej nad Perą miały zostać zwrócone bezpośrednio do tamtejszego kościoła św. Klary. W imieniu kościoła i klasztoru San Domenico w Genui darowiznę przyjęli między innymi ojciec Domenico Michiel, biskup cypryjskiej Famagusty (pozostającej wówczas pod panowaniem genueńskim), oraz zakonnicy z tego klasztoru, profeso-

13 (1877-1884), s. 987-992. Akcja została dotychczas omówiona przez P. Baghino, Tra erudizione e orgoglio municipale. La questione delle opere diarte trasportate a Genova da Pera nel 1461, w: Le "Notizie dei Professori del Disegno in Liguria" di Federigo Alizeri. Una esperienza informatica di analisi testuale, indicizzazione e consultazione interattiva, a cura di L. Kaiser, Genova 1995, s. 87-98; V. Polonio, A Genova tra XIV e XV secolo. Icone e reliquie d'Oltremare, w: Intorno al Sacro Volto. Genova, Bisanzio e il Mediterraneo (secoli XI-XIV), a cura di A.R. Calderoni Masetti, C. Dufour Bozzo, G. Wolf, Venezia 2007 (Collana del Kunsthistorisches Institut in Florenz, 11), s. 123-134, oraz R. Quirini-Popławski, „Ex partibus orientalibus translata ad hanc urbem". The Evacuation of Elements of Church Decoration from Pera to Genoa in 1461, w: Travels and Mobilities in the Middle Ages. From the Atlantic to the Black Sea, ed. by M. O'Doherty, F. Schmieder, Turnhout 2015 (International Medieval Research, vol. 21), s. 291-312.

16 L.T. Belgrano, Prima serie..., s. 272, przeł. R.Q.P. 
rowie teologii - przeor Filippo de Opiciis, Desiderio de Rapallo oraz Bernardo de Salvaticis. W skład daru wchodziły przede wszystkim szaty, głównie liturgiczne, jak ornat, zestaw szat diakona i subdiakona oraz pumarium, wykonane $\mathrm{z}$ białej kamchy ze złotymi fryzami zawierającymi herby Genui (pumarium posiadało ponadto wykonany greckimi literami napis „Mater Dei”), trzy płócienne alby ze zdobionymi złotem rękawami, dwie stuły i trzy manipularze z białej kamchy wraz z trzema złotymi humerałami, alba z białego płótna $\mathrm{z}$ dodatkiem niebieskiej kamchy, ze stułą, manipularzem oraz humerałem, dwie większe tunicelle dla subdiakonów, haftowane złotymi nićmi, szata z karmazynowej kamchy z herbem Giustinianich, szata ze szkarłatnej kamchy $z$ herbami Giustinianich i di Pagana oraz fryzem $z$ herbem Komuny (zapewne Genui), szata $z$ białej kamchy $\mathrm{z}$ herbem Komuny, ornat $\mathrm{z}$ różnokolorowej kamchy $\mathrm{z}$ Kaffy $\mathrm{z}$ fryzem niebieskim lamowanym złotem, cztery cingula (pasy), jedna komża, dwa blavia, czyli małe szaty na maestà lamowane złotem oraz pięć obrusów. Poza tym ofiarowano kilka naczyń, takich jak srebrny złocony kielich $\mathrm{z}$ pateną ( $\mathrm{z}$ herbem rodu Spinola), srebrny trybularz oraz dwie ampułki srebrne złocone ${ }^{17}$.

Co więcej, z dokumentu wynika, że Marietta di Pagana dokonała też w 1425 roku fundacji samego kościoła św. Klary w Perze. W związku z tym możemy przyjąć, iż jego budowa miała zapewne miejsce w drugiej ćwierci XV wieku. Być może przy tym kościele istniał klasztor należący do zakonu klarysek. Świątynia ta znajdowała się na terenie przedmieścia Lagirio, w sąsiedztwie zamku Galaty (zamku Krzyża Świętego) oraz znajdującej się w murach miejskich bramy Porta S. Chiara (zwanej później Mumhane Kapıs1). Wiadomo, że kościół istniał jeszcze w 1540 roku, gdy wspomniał o nim fran-

17 Zob. ibidem, s. 272-273; G. Matteucci, La missione francescana di Costantinopoli, vol. 1: La sua antica origine e primi secoli di storia (1217-1585), Firenze 1971 (Biblioteca di Studi Francescani, 9), s. 228-229; V. Polonio, A Genova tra XIV e XV secolo..., s. 127, 133. 
cuski podróżnik Pierre Gilles (Petrus Gyllius), lecz jego dalsze losy pozostają niejasne ${ }^{18}$.

Prawie identyczna sytuacja miała miejsce około miesiąca później, 19 lutego 1456 roku. Potomkowie Tommaso Spinoli, bogatego genueńskiego kupca z Pery, przekazali do tego samego kościoła San Domenico szaty liturgiczne, które Spinola pierwotnie ufundował dla kościoła Dominikanów w Perze, a po zajęciu jej przez Turków rozkazał przenieść do Genui. Były to ornat z paramentami dla diakona i subdiakona oraz paliusz, przetykane złotymi nićmi. Podobnie jak w przypadku darowizny Marietty di Pagana, miały one powrócić do miejsca pierwotnego przeznaczenia, jeśli Deo permittente Pera wróciłaby w ręce chrześcijan. Co ciekawe, w zamian za ten dar bracia pozwolili na zbudowanie kaplicy św. Mikołaja przy ich kościele, gdyż zmarły miał wcześniej taką w kościele tego zakonu w Perze ${ }^{19}$.

Jak napisano wyżej, podobne działania zmierzające do ewakuacji cennych przedmiotów z wnętrz łacińskich kościołów Pery w bezpieczniejsze miejsca podjęli także przedstawiciele zakonów opiekujących się niektórymi klasztorami. Z relacji dominikanina Leonarda z Chios, łacińskiego arcybiskupa Mityleny, wiadomo na przykład, że dominikanie rezydujący przy wspomnianym kościele św. Pawła (il. 2) schronili się na należącą wówczas do Genueńczyków wyspę Chios, zabierając z sobą relikwie i najcenniejsze elementy kościelnego wyposażenia. Ostatecznie miały one trafić do Genui, zapewne do

18 Zob. E. Dalleggio D’Alessio, Recherches sur l'histoire..., s. 36-37; R. Janin, La géographie ecclésiastique..., s. 587; G. Matteucci, La missione francescana..., s. 229-236; C. Barsanti, Il panorama di Cristoforo Buondelmonti..., s. 63. Być może kościół ten przejął z czasem wezwanie oraz część wyposażenia kościoła św. Antoniego, stojącego pierwotnie na terenie zachodniego przedmieścia Pery, Spigi.

19 Zob. L. Balletto, I Genovesi e la conquista turca di Costantinopoli (1453). Note su Tommaso Spinola e la sua famiglia, „Acta historica et archaeologica mediaevalia” 26 (2005) (Homenatge a la Professora Dra. Carme Batlle i Gallart), s. 810-815; A. Lercari, 'Pro redemptione anime mee', w: Mercanti. Gli uomini d'affari a Genova nel medioevo, a cura di G. Olgiati, Genova 2013, s. 145-147; F. Özden Ercan, The Genoese of Pera..., s. 47, 50. 
klasztoru Santa Maria di Castello, podczas gdy archiwalia zakonne przechowywane przy klasztorze w Perze przekazano do Kaffy ${ }^{20}$.

Nie wszystkie te plany udało się jednak w pełni zrealizować. Ojciec Placido de Podio, przeor benedyktyńskiego klasztoru Santa Maria della Misericordia (il. 3), już podczas oblężenia Konstantynopola zorganizował transport relikwii i najcenniejszych obiektów kultowych również na Chios. Zachował się szczegółowy spis tych przedmiotów znajdujących się $\mathrm{w}$ dwóch skrzyniach, sporządzony przez ojca Giovanniego Battistę de Tabia w domu tegoż zakonu na Chios w 1473 roku (z dopiskami z lat 1475 i 1478) w obecności ojca Giovanniego Bartolomeo de Podio. W spisie tym wymienionych zostało ponad dwadzieścia drogocennych tkanin, czasami wykonanych $\mathrm{z}$ kamchy, $\mathrm{z}$ reguły zdobionych złotymi nićmi, $\mathrm{w}$ tym ornaty oraz antependium ołtarzowe. Dekoracją wyróżniała się grupa szat z przedstawieniami figuralnymi: proroków, Matki Boskiej z Dzieciątkiem wśród aniołów oraz - dwukrotnie - papug. Z kolei kapa wykonana $\mathrm{z}$ błękitnej tkaniny $\mathrm{z}$ kapturem wyróżniała się srebrną klamrą zdobioną półszlachetnymi kamieniami. Ponadto na Chios znajdowały się liczne inne tkaniny, naczynia liturgiczne, dwadzieścia fragmentów pozłacanych miedzianych antependiów i trzy strusie jaja $^{21}$. W latach 1478-1486 toczyła się prawdziwa walka o przejęcie dawnego klasztoru Benedyktynów, w której uczestniczyli franciszkanie i rozmaite osobistości mieszkające w Perze ${ }^{22}$. W sierpniu 1478 roku większość wymienionych przedmiotów została przez ojca Giovanniego de Tabia przekazana Pellegro De Marini, który przejął je

20 Zob. R. Janin, La géographie ecclésiastique..., s. 592; C. Monge, Domenicani a Costantinopoli/Istanbul. Continuità ed evoluzione di una missione, w: Domenicani a Costantinopoli..., s. 29-30. Niektóre rękopisy przechowywane, a być może i powstałe w tym klasztorze, trafiły w nieznanych bliżej okolicznościach między innymi do Biblioteki Watykańskiej oraz biblioteki monasteru Vatopedi na Górze Athos, zob. N. Melvani, Dominicans in Byzantium..., s. 36.

${ }_{21}$ Zob. L.T. Belgrano, Seconda serie..., s. 994-996; V. Polonio, Santa Maria della Misericordia..., s. 413-414.

22 Zob. R. Janin, La géographie ecclésiastique..., s. 586. 
w imieniu przeora Placido de Podio. Celem tej operacji było przewiezienie ich do klasztoru San Gerolamo della Cervara w miejscowości Santa Margherita Ligure koło Genui, należącym (tak samo jak Santa Maria della Misericordia w Perze) do kongregacji Santa Giustina w Padwie. 30 stycznia 1481 roku doża genueński Battista de Campofregoso wraz z Consiglio degli Anziani wysłali jednak list do władz Chios, by opiekujący się dotąd tymi przedmiotami Pellegro De Marini wydał je ojcu Cipriano de Casanova, przedstawicielowi klasztoru Santa Maria della Misericordia. Jak można się więc domyślać, zamiast pod Genuę trafiły one z powrotem do Pery ${ }^{23}$.

Inną drogą niektóre przedmioty pochodzące $\mathrm{z}$ klasztoru benedyktyńskiego w Perze trafiły jednak do Italii. W 1475 roku franciszkańska tercjarka Isabella Spinola, córka Francesca Draperia i wdowa po Tommasie Spinoli, reprezentując interesy tego klasztoru, przywiozła je do Rzymu i wręczyła papieżowi Sykstusowi IV. Zostały one określone ogólnie jako „przywiezione ze Wschodu”. Był to posrebrzany krzyż - stauroteka ozdobiona drogocennymi kamieniami, zaś końcówki jego ramion wizerunkami i greckimi inskrypcjami. Prawdopodobnie zawierał on również relikwie św. Mikołaja (kształt tego relikwiarza był więc podobny do Croce degli Zaccaria, przechowywanego dziś w skarbcu katedry genueńskiej). Papież otrzymał również relikwię głowy męczennika Andrzeja z Molassany, najprawdopodobniej identycznego ze świętym Kościoła prawosławnego Andrzejem Argentesem (Argyris) z Chios, zmarłym w 1465 roku i pochowanym w niesprecyzowanym bliżej kościele Matki Bożej w Perze, który wydaje się identyczny z Santa Maria della Misericordia ${ }^{24}$.

23 Zob. L.T. Belgrano, Seconda serie..., s. 996-997; V. Polonio, Santa Maria della Misericordia..., s. 402-403.

24 Zob. R. Santamaria, Le memorie d'arte sulle rotte dei mercant genovesi, w: Mercanti. Gli uomini d’affari..., s. 41-42. O okolicznościach misji Isabelli do Watykanu, zob. G. Pistarino, Chio dei Genovesi nel tempo di Cristoforo Colombo, Roma 1995, s. 308-309. 


\section{Z Chios do Genui}

Warto zaznaczyć, że wspomniane tu działania dominikanów i benedyktynów o kilka miesięcy poprzedziły bullę wydaną przez Mikołaja V 8 października 1453 roku. Papież wzywał w niej wiernych (zarówno duchownych, jak i świeckich) pod karą ekskomuniki do ratowania przedmiotów i ksiąg liturgicznych przez rozproszeniem, nawet za cenę ich wykupywania $\mathrm{z}$ rąk tureckich. W bulli zaznaczono jednak, że przedmioty powinny powrócić do Pery w przypadku ponownego przejęcia kontroli nad nią przez chrześcijan ${ }^{25}$. Być może to wskutek tej bulli, choć w nieznanych bliżej okolicznościach, na Chios znalazła się znacznie większa liczba przedmiotów pochodzących z kościołów Pery. Rzeczy te zostały wysłane na stosunkowo nieodległe Chios zapewne dlatego, by poczekać tam bezpiecznie na dalszy rozwój wypadków. Wobec gasnącej nadziei na rychły powrót władzy genueńskiej nad Złoty Róg zadecydowano o zapakowaniu tych rzeczy do dwóch skrzyń i dwóch beczek, które pod koniec 1460 roku pod opieką Benedetta Salvagi załadowano na statek należący do Luciana de Marini. Na początku 1461 roku statek ten przybił do portu w Genui, a wartość przywiezionych na nim przedmiotów spowodowała interwencję władz Republiki ${ }^{26}$.

23 stycznia 1461 roku Signoria genueńska upoważniła więc sześciu officiales pochodzących $\mathrm{z}$ najznakomitszych rodów do przeprowadzenia zakrojonej na dużą skalę akcji zgromadzenia wszystkich przedmiotów przywiezionych do Genui na statku Luciana de Marini, gdziekolwiek i u kogokolwiek by się znajdowały, a następnie planowego przekazania ich do wybranych przez officiales kościołów metropolii („in illis templis ubi eis melius videbitur”). Byli to: Giacomo Bracelli, kanclerz Komuny, Benedetto Salvago, Guirardo Spinola,

25 Zob. C. Monge, Domenicani a Costantinopoli..., s. 30.

26 Zob. V. Polonio, A Genova tra XIV e XV secolo..., s. 127-128; P. Baghino, Tra erudizione..., s. 87. Polonio przypuszcza, że jednym z powodów tej interwencji były dokonane już przywłaszczenia niektórych przedmiotów. 
Lodisio Franchi (De Bulgaro), Niccolò de Marini oraz Marco Doria. Officiales mieli prawo do zwrotu wszelkich kosztów poniesionych $\mathrm{w}$ ramach wypełniania tego zadania. Co dla nas szczególnie istotne, ponieważ warunkiem przekazania tych przedmiotów była obietnica ich bezwzględnego zwrotu na wypadek stałego odzyskania Pery przez Genuę, ich oddawanie kościołom genueńskim musiało zostać udokumentowane odpowiednim szczegółowym spisem obejmującym też szacunkową wartość każdej rzeczy. Niestety, w zachowanych dokumentach nie odnotowano świątyń, z których pochodziły te przedmioty. Ze względu na powyższy warunek, dokumenty zawierające informacje o kościele pochodzenia danego obiektu musiały istnieć, lecz po prostu nie zachowały się ${ }^{27}$. Jak się jednak wydaje, przedmioty pochodzące ze świątyń klasztornych w Perze trafiały z reguły do kościołów genueńskich należących do tych samych zakonów.

Już 22 stycznia officiales zwrócili się do Luciana de Marini o bezzwłoczne przekazanie przywiezionych dwóch skrzyń i dwóch beczek, zaś 9 lutego władze Republiki nakazały mnichowi kartuskiemu Francescowi Calvowi zwrot brewiarza i innych ksiąg, które trzymał u siebie ${ }^{28}$.

Okazało się, że zrealizowanie tych zamierzeń nie będzie łatwe. Franciszkanie i dominikanie wyrazili obawę, że przedmioty pochodzące $\mathrm{z}$ ich kościołów w Perze mogą trafić do świątyń diecezjalnych. Wskazywano, że nie wiadomo, kto miałby pokryć koszty transportu tych rzeczy do Genui oraz ewentualnej utraty ich wartości. 13 lutego władze Genui zwróciły się więc do papieża Piusa II z prośbą o pomoc $\mathrm{w}$ przeprowadzeniu tego przedsięwzięcia, tak by decyzjom osób, którym powierzono wykonanie tego zadania, nadał również swoją sankcję (szczególną wagę przykładano przy tym do losu ksiąg). Ponadto poproszono go także o zgodę na sprzedaż jednego z trzydzie-

27 Zob. L.T. Belgrano, Prima serie..., s. 274-275; P. Baghino, Tra erudizione..., s. 87; V. Polonio, A Genova tra XIV e XV secolo..., s. 127-128, 132. Guirardo Spinola i Benedetto Salvago byli uchodźcami ze Wschodu, zapewne z Pery.

28 Zob. L.T. Belgrano, Prima serie..., s. 275-276. 
stu przywiezionych kielichów dla pokrycia wydatków ponoszonych przez officiales. Równocześnie jeden z nich, kanclerz Giacomo Bracelli, zwrócił się do sekretarza apostolskiego Bartolomea di Framura o zgodę na sprzedaż innych, mniej cennych przedmiotów, lecz co najmniej do kwietnia nie otrzymał od niego odpowied $z^{29}$.

Jak się okazuje, za przekazywane przedmioty zarządcy kościołów musieli ostatecznie uiścić kaucję adekwatną do szacowanej wartości daru. Problem polegał na tym, że officiales wybrali kościoły najbardziej potrzebujące, pozbawione wyposażenia, tym samym - najbiedniejsze. Potrzebne więc było znalezienie mecenasów skłonnych wypłacić odpowiednie sumy pieniężne, na co z kolei kościoły musiały otrzymać odpowiednią zgodę arcybiskupa ${ }^{30}$.

\section{Przedmioty przekazane kościołom genueńskim w 1461 roku}

Niemal cała akcja rozegrała się w okresie od czerwca do grudnia 1461 roku. Dzięki zachowanym dokumentom możemy nie tylko dość szczegółowo zrekonstruować jej przebieg, lecz także scharakteryzować przedmioty, które w jej wyniku znalazły się w poszczególnych kościołach Genui. Jak podkreśliła Valeria Polonio, przedmioty pochodzące z kościołów Pery trafiły w zdecydowanej większości do genueńskich kościołów klasztornych o fundacji niesięgającej wstecz dalej niż koniec XIV wieku ${ }^{31}$.

Pierwszy chronologicznie dar trafił do katedry genueńskiej. 19 czerwca ośmiu radców i jedenastu współbraci funkcjonującej przy katedrze Devozione di San Giovanni upoważniło jej dwóch

29 Zob. ibidem, s. 274-275; V. Polonio, A Genova tra XIV e XV secolo..., s. $128,132$.

30 V. Polonio, A Genova tra XIV e XV secolo..., s. 128.

31 Zob. ibidem, s. 129. 
przeorów, Galeotta Lomellina i Niccolò Adorno-Campanara, do odebrania przedmiotów o wartości 750 lirów, co najprawdopodobniej stało się następnego dnia. „Dla kultu i ozdoby” kaplicy św. Jana Chrzciciela (ad cultum et ornatum dicte capelle) trafiły tu więc dwie ozdobne płyty srebrne (z wizerunkami i literami greckimi), srebrna lampa oraz dwa świeczniki z kryształu i srebra.

26 czerwca Benedetto Nigrono, przeor benedyktyńskiego klasztoru i szpitala Sant’Antonio di Prè, odebrał przedmioty o wartości 210 lirów: kryształowy relikwiarz (lub relikwiarze) św. Antoniego, ze srebrnymi ozdobami, dwa kielichy z patenami oraz łódkę z łyżką (wszystkie srebrne), diadem oraz inne, bliżej niesprecyzowane rzeczy $^{32}$.

27 czerwca klasztor Kanoniczek Lateraneńskich Santa Maria delle Grazie otrzymał przedmioty o wartości 102 lirów: maestà Matki Boskiej ozdobioną srebrem (w srebrnej sukience?), mały krzyż srebrny na postumencie (wagi sześciu uncji), srebrny kielich z pateną (wagi funta i dziewięciu uncji), szatę ze złotymi galonami oraz ornat $\mathrm{z}$ herbem rodu Spinola.

1 lipca Stefano di Antonio di Turilio, przeor klasztoru Santa Brigida, przejął przedmioty o wartości 105 lirów: dwa srebrne kielichy z patenami (wagi czterdziestu jeden uncji), ołtarzyk kryształowy ze złoconą dekoracją i relikwiami św. Katarzyny oraz obraz w srebrnej sukience ${ }^{33}$.

32 Być może przedmioty te pochodziły $\mathrm{z}$ benedyktyńskiego kościoła Santa Maria della Misericordia della Cisterna w Perze.

33 Wedle Anny Spinelli relikwie św. Katarzyny mogły około 1300 roku znajdować się w konstantynopolitańskim kościele Dominikanów, jednak już w 1403 roku były przechowywane w klasztorze Franciszkanów w Perze, gdzie widziało je kastylijskie poselstwo, któremu przewodniczył Ruy Gonzáles de Clavijo (Dal mare di Alboran a Samarcanda. Diario dellambasciata castigliana a Tamerlano (1403-1406), a cura di A. Spinelli, Ravenna 2004, s. 103; R. Quirini-Popławski, 'Stormy Adventures' of the Relics of Pera, w: Sacrum w mieście. Wymiar religijny, kulturalny i społeczny, t. 1: Średniowiecze i wczesna epoka nowożytna, red. D. Quirini-Popławska, Ł. Burkiewicz, Kraków 2016, s. 69, 80). 
2 lipca siostra Tommasa Gambacurta, ksieni dominikanek z klasztoru Corpo di Cristo (dawniej San Silvestro) otrzymała (za 171 lirów): srebrny kielich z pateną (wagi dwóch funtów i trzech uncji), maestà w srebrnej sukience, srebrny trybularz z łódką i łyżką (wagi czterech funtów) oraz krzyż obity srebrną blachą (?).

Również 2 lipca franciszkanki z klasztoru San Paolo de Capite Arene (de Via Nova) otrzymały (za 80 lirów): srebrny trybularz z łódką i łyżką oraz obraz Opłakiwanie Chrystusa.

Brat Simonetto di Ripalta 3 lipca zabrał dla kościoła San Bartolomeo della Certosa (za 100 lirów): srebrny kielich z pateną (wagi czterech funtów i trzech uncji) oraz maestà w srebrnej sukience.

7 lipca benedyktyni z klasztoru San Benigno di Capofaro otrzymali dwa srebrne kielichy z patenami oraz ołtarzyk z relikwiami św. Ignacego (w sumie za 112 lirów).

8 lipca klasztor Santa Maria dei Servi otrzymał (za 79 lirów): kielich (wagi funta i dwóch uncji), wielki krzyż i maestà z Matką Boską w srebrnej sukience.

Benedyktyni z San Niccolò del Boschetto odebrali 4 września (za 80 lirów): ołtarzyk zdobiony kryształem, perłami i sztucznymi klejnotami (iocalibus confractis) z cząstką kości św. Bazylego oraz srebrny krzyż z amblis (bursztynami?) i kryształową gałką ${ }^{34}$.

Eremitki z San Silvestro otrzymały 17 września (za 40 lirów): srebrny kielich z pateną oraz maestà ze św. Janem Chrzcicielem ${ }^{35}$.

34 Zapewne te relikwie św. Bazylego, jak i wspomniane wyżej relikwie św. Ignacego, były w 1403 roku przechowywane w klasztorze franciszkańskim w Perze (zob. Dal mare di Alboran..., s. 105; R. Quirini-Popławski, 'Stormy Adventures'..., s. 69$70,80)$.

35 Zob. L.T. Belgrano, Prima serie..., s. 277-281; idem, Seconda serie..., s. 988-983; P. Baghino, Tra erudizione..., s. 89, 92-93; V. Polonio, A Genova tra XIV e XV secolo..., s. 128, 132-134. Odnośnie daru dla kościoła Sant’Antonio di Prè (z powołaniem się na dokument z 1466 roku), zob. także: L. Tagliaferro, L“Eleusa" di Pera a Genova, „Bollettino dei Musei civici genovesi” 6 (1984), s. 8, zaś dla San Benigno di Capofaro: G. Salvi, La Distruzione della Badia Genovese di Capo Faro, „Benedictina” 15 (1968), s. 343. 
Najdroższe dary otrzymały jesienią 1461 roku dwa klasztory zakonów mendykanckich, głównie dzięki pomocy finansowej przedstawicieli rodu Giustiniani. W dniach 17 września oraz 6 i 7 listopada franciszkańskie sanktuarium Santa Maria del Monte (Madonna del Monte in Val Bisagno) otrzymało przedmioty o wartości 1430 lirów (il. 4): trzy srebrne kielichy z patenami, srebrny relikwiarz św. św. Andrzeja Apostoła i Mikołaja, zdobiony perłami i kryształem, dwie maestà z Madonnami, ornat z karmazynowego atłasu ze złotymi fryzami, niesprecyzowany bliżej przedmiot wykonany z kamchy zdobionej filigranem i srebrnymi aplikacjami (?) (plebiario di camocato d’anofato con smalti di argento), mały złocony krzyż, 187 ksiąg, a następnie - relikwiarz z ramieniem św. Anny, ze złota, srebra, zdobiony klejnotami i perłami ${ }^{36}$.

Drugi co do wartości dar (894 liry) otrzymał dominikański klasztor Santa Maria di Castello (il. 5), dokąd 1 października i 16 grudnia trafiły: srebrny relikwiarz ramienia św. Praksedy z klejnotami, cztery srebrne kielichy i trzy takie pateny, srebrny trybularz z łódką i łyżką, srebrne tabernakulum na Corpus Domini, ołtarzyk z posrebrzanej miedzi, z kryształem, srebrny relikwiarz św. Dominika z klejnota$\mathrm{mi}$, krzyż srebrny pozłacany z kryształową gałką, srebrny relikwiarz św. Piotra Męczennika, pewna liczba relikwiarzy ze złota i srebra (?), 3 korporały, tasiemka, 24 księgi, maestà z Matką Boską w srebrnej sukience $\mathrm{z}$ perłami i pierścieniami (?), a ponadto relikwie bez ozdobnych relikwiarzy - cząstki Krzyża Świętego, głowy św. Pawła Apostoła, św. Bartłomieja Apostoła, św. Łazarza, św. Dionizego, biskupa i mę-

${ }^{36}$ Zob. L.T. Belgrano, Prima serie..., s. 278-281; P. Baghino, Tra erudizione..., s. 88; V. Polonio, A Genova tra XIV e XV secolo..., s. 129, 134; G. Ameri, Reliquiario del braccio di Sant'Anna, w: Mandylion. Intorno al Sacro Volto, da Bisanzio a Genova, a cura di G. Wolf, C. Dufour Bozzo, A.R. Calderoni Masetti, Milano 2004, s. 254258. Wymienione tu relikwiarze św. św. Andrzeja i Mikołaja oraz Anny były w 1403 roku z pewnością przechowywane w klasztorze franciszkańskim w Perze (Dal mare di Alboran..., s. 102, 105; R. Quirini-Popławski, 'Stormy Adventures'..., s. 69-70, 80). O relikwiarzu ramienia św. Anny zob. niżej. 
czennika, św. Konstantyna cesarza, fragment szyi św. Agaty i szczątki licznych innych świętych ${ }^{37}$.

Jesienią mniejsze dary trafiły jeszcze w dwa miejsca: do kościoła San Giuliano d’Albaro (5 października, za 68 lirów): maestà z Matką Boską w srebrnej sukience i srebrny kielich z pateną (wagi dwóch funtów i pięciu uncji), oraz do zakrystii katedry San Lorenzo (27 października): krzyż srebrny z dwoma szafirami, dwoma rubinami oraz czterdziestoma czterema perłami, kryształowy relikwiarz z palcem św. Wawrzyńca zdobiony srebrem i dwudziestoma perłami oraz kapa. Dopiero w sierpniu 1476 roku kościół Santa Maria della Cella (pozostający pod opieką benedyktynów z San Benigno di Capofaro) otrzymał srebrny relikwiarz ramienia św. Pantalejmona z napisem wykonanym literami greckimi ${ }^{38}$.

Dzięki dokumentom powstałym w ramach opisanej wyżej akcji uzyskujemy więc częściową wiedzę na temat wyposażenia kościołów Pery. Kilkukrotne wzmiankowanie napisów greckich znajdujących się na ofiarowanych obiektach wskazuje, że w świątyniach tych znajdowała się znaczna liczba przedmiotów o charakterze bizantyńskim, co potwierdza też kilka zachowanych dzieł ${ }^{39}$. Należy jednak wziąć

37 Zob. F. Alizeri, Guida artistica per la città di Genova, I, Genova 1846, s. 365-366; L.T. Belgrano, Prima serie..., s. 279-280; idem, Seconda serie..., s. 992; R.A. Vigna, Storia cronologica del convento di S. Maria di Castello, Genova 1889 („Atti della Società ligure di storia patria” 21), s. 123-125; P. Baghino, Tra erudizione..., s. 87; V. Polonio, A Genova tra XIV e XV secolo..., s. 129, 134. Wspomniane tu relikwiarze św. św. Praksedy, Dominika oraz Piotra Męczennika pochodziły zapewne $\mathrm{z}$ dominikańskiego klasztoru w Perze, jednak relikwie św. Dionizego i cząstka Krzyża Świętego w 1403 roku prawdopodobnie znajdowały się w tamtejszym klasztorze franciszkańskim (zob. R. Quirini-Popławski, 'Stormy Adventures'..., s. 80).

38 Zob. V. Polonio, A Genova tra XIV e XV secolo..., s. 130, 134. Relikwiarz św. Pantalejmona został co prawda przywieziony z Pery, lecz pochodził z Syrii. W 1403 roku, podobnie jak relikwiarz św. Wawrzyńca, znajdował się w klasztorze franciszkańskim w Perze (zob. R. Quirini-Popławski, 'Stormy Adventures'..., s. 69,80$)$.

39 Nicholas Melvani zakłada, że klasztor dominikański w Perze mógł być miejscem, w którym powstawały dzieła sztuki o hybrydowym, grecko-łacińskim 
pod uwage możliwość sprowadzenia ich do łacińskich kościołów Pery z innych miejsc, zwłaszcza z greckich świątyń samego Konstantynopola. Można w tym kontekście wspomnieć opinię genueńskiego historyka Niccolò Perassa z jego niepublikowanego dzieła „Chiese di Genova” z 1770 roku, wedle którego podczas dziesięcioletniego (sic!) oblężenia tureckiego do Pery trafiły jakoby najcenniejsze relikwie pochodzące z kościołów samego Konstantynopola. Miało tak się stać z woli cesarza Konstantyna XI (1449-1453) za pośrednictwem jego genueńskiej małżonki Cateriny Gattilusio (zm. 1442), córki Dorina Gattilusia. Mimo kilku oczywistych błędów historycznych historia ta może mieć w sobie pewne elementy prawdy. Hipotetycznie można założyć, że w obliczu zagrożenia tureckiego pewne przedmioty mogły trafić z Konstantynopola do pozornie bezpieczniejszej Pery, tak jak później zostały one wywiezione stamtąd na Chios i do Genui, lecz wersja ta jest mało prawdopodobna ${ }^{40}$. Można przypuszczać, że przede wszystkim cenne relikwie (choć niekoniecznie same relikwiarze) rzeczywiście pochodziły z greckich kościołów Konstantynopola, lecz w ręce łacińskie trafiły one zapewne już w okresie Cesarstwa Łacińskiego, zaś do Genueńczyków - w 1261 roku $^{41}$.

O tym, że nawet poszczególni Genueńczycy mieli tego typu cenne relikwie, świadczy przykład Battisty Paterio fu Antonio, który w 1484 roku przebywał na Chios. Był on wtedy w posiadaniu stauroteki zawierającej „non parvam partem ligni vere crucis domini nostri Ihesu Christi”, która miała niegdyś należeć do cesarza bizantyńskiego. 4 października tego roku Antonio Doria fu Oliverio podejmował starania, by Battista Paterio podarował tę relikwię franciszkańskiemu klasztorowi Madonna del Monte w Genui ${ }^{42}$. Można stąd

charakterze kulturowym, analogicznie do niektórych ikon kreteńskich (zob. N. Melvani, Dominicans in Byzantium ..., s. 47-49).

40 Treść pracy Perassa, przechowywanej wówczas w Archivio di Stato w Turynie, zrelacjonował w 1889 roku R.A. Vigna, Storia cronologica del convento..., s. 123125, opowiadając się jednak przeciw jego wersji.

41 Zob. R. Quirini-Popławski, 'Stormy Adventures'..., s. 71-72.

42 Zob. R. Santamaria, Le memorie d'arte..., s. 42. 
domniemywać, że relikwiarz ten trafił na Chios z klasztoru franciszkańskiego w Perze. Rzeczywiście, w 1487 roku wspomniany kościół genueński otrzymał złoty krzyż zawierający cząstkę Krzyża Świętego, niegdyś czczony w kaplicy cesarskiej w Konstantynopolu ${ }^{43}$.

\section{Zamiast podsumowania. Późniejsze losy przedmiotów}

Niewiele możemy powiedzieć o późniejszych losach wymienionych wyżej przedmiotów, choć niektóre z nich do dziś znajdują się $\mathrm{w}$ Genui. Wiemy jedynie, że relikwie z Pery, nie tylko podarowane w 1461 roku dominikańskiemu kościołowi Santa Maria di Castello, lecz także innym świątyniom genueńskim (być może pochodzące również z innych niż Pera kolonii wschodnich należących niegdyś do Genui), zostały w maju 1610 roku złożone w znajdującej się przy kościele kaplicy noszącej wówczas wezwanie Assunty (obecnie św. Błażeja) ${ }^{44}$. Do drugiej połowy XIX wieku w kościele tym znajdował się także obraz Madonna di Pera (il. 6) w srebrnej sukience, najprawdopodobniej wykonanej pod koniec XIII lub w pierwszej ćwierci XIV wieku, i przekazany tam 16 grudnia 1461 roku. Niestety, 14 maja 1878 roku złodzieje, którzy wkradli się do kościoła, zniszczyli obraz oraz pocięli jego sukienkę. Nieco później proboszcz Tommaso Campo-Antico odzyskał prawie wszystkie części sukienki, zlecił jej odtworzenie wraz z uzupełnieniem brakujących fragmentów. Na podstawie fotografii, wykonanej wcześniej z polecenia Società Ligure di Storia Patria, polecił zrekonstruować

43 Zob. C. Less, Santuario di Nostra Signora del Monte, w: Fonti per la Storia della Critica d'Arte (FOSCA), http://www.fosca.unige.it/gewiki/index.php/Santuario_di_ Nostra_Signora_del_Monte (dostęp: 3.02.2018).

44 Zob. L.T. Belgrano, Prima serie..., s. 281-284, 336; P. Baghino, Tra erudizione..., s. 90, przyp. 5; R. Quirini-Popławski, 'Stormy Adventures'..., s. 75, 80. 
także sam obraz. Nawet ta zrekonstruowana wersja została skradziona $\mathrm{z}$ kościoła, prawdopodobnie przed 1929 rokiem $^{45}$.

Inny obraz Matki Boskiej, zapewne z XIV wieku, trafil do Museo di Sant'Agostino w Genui. Obraz, także nazywany Madonna di Pera (il. 7), pochodzi z benedyktyńskiego kościoła Sant’Antonio di Prè $\mathrm{w}$ Genui ${ }^{46}$. Wśród przedmiotów z Pery, które w 1461 roku znalazły się w tym kościele, nie wymieniono żadnych obrazów, choć darowano tam także pewną liczbę niesprecyzowanych bliżej „rzeczy”. Jest jednak również prawdopodobne, że obraz ten trafił do Genui nieco później, ze wspomnianego już benedyktyńskiego klasztoru Santa Maria della Misericordia w Perze, który w 1486 roku został podporządkowany klasztorowi Sant'Antonio ${ }^{47}$. Dopiero w pierwszej połowie XIX wieku została odnotowana informacja, że wedle tradycji znajdujący się wówczas w tym genueńskim kościele obraz Matki Boskiej z Dzieciątkiem z Pery został namalowany przez św. Łukasza ${ }^{48}$. Pod koniec tego wieku tradycję tę związano z przedstawieniem maryjnym wtórnie włączonym w drugiej połowie XVII wieku do obrazu Święty Mikołaj z Miry autorstwa Giovanniego Andrei Carlone-

45 Zob. F. Alizeri, Guida artistica..., s. 365-366; L.T. Belgrano, Tavole a corredo della prima serie di documenti riguardanti la colonia di Pera, dodatek do: „Atti della Società Ligure di Storia Patria” 13 (1877-1884), s. 8-9, tab. V; R.A. Vigna, Storia cronologica del convento..., s. 123, 125; L. Tagliaferro, L“Eleusa” di Pera a Genova..., s. 10 (przyp. 8), 23 (il. 12); P. Baghino, Tra erudizione..., s. 87-88, 9091; C. Di Fabio, Bisanzio a Genova fra XII e XIV secolo. Documenti e memorie d'arte, w: Genova e l'Europa mediterranea. Opere, artisti, commitenti, collezioni, a cura di P. Boccardo, C. Di Fabio, Milano 2005, s. 45-46; G. Ameri, Nuove considerazioni sul reliquiario del braccio di S. Anna nel tesoro del Duomo di Genova, „Mitteilungen des kunsthistorischen Institutes in Florenz" 53/2-3 (2009), s. 189.

46 Zob. M. Cordaro, Relazione di restauro del dipinto del sec. XIV: Madonna col Bambino - Genova, Galleria di Palazzo Bianco, „Bollettino dei Musei civici genovesi” 6 (1984), s. 5; P. Baghino, Tra erudizione..., s. 93.

47 Zob. L.T. Belgrano, Seconda serie..., s. 988-989; V. Polonio, Santa Maria della Misericordia..., s. 420; L. Tagliaferro, L'Eleusa” di Pera a Genova..., s. 8, 11-22 (il. 1-11); V. Polonio, A Genova tra XIV e XV secolo..., s. 130, 133.

48 Obraz ten miał jednak zawierać wokół przedstawienia środkowego figury dwunastu apostołów (zob. L. Tagliaferro, L“Eleusa” di Pera a Genova..., s. 7). 
go. W przeciwieństwie do innych elementów wyposażenia kościoła Sant’Antonio interesujący nas obraz zaraz po zamknięciu świątyni w 1891 roku trafił do miejskich zbiorów artystycznych w Palazzo Bianco $^{49}$.

Trzecim zachowanym do dziś dziełem, które trafiło do Genui z Pery, jest tak zwany relikwiarz na ramię (w rzeczywistości jest to kość udowa) św. Anny (il. 8), datowany przez Gianlucę Ameriego na początek XIV wieku (?) i uważany za dzieło wykonane w Konstantynopolu bądź w samej Perze. Jesienią 1461 roku trafił on do franciszkańskiego sanktuarium Madonna del Monte in Val Bisagno i został umieszczony w ołtarzu znajdującym się w prawym ramieniu transeptu, które w efekcie zostało zamienione na kaplicę poświęconą św. Annie. Relikwiarz był wystawiany na tym ołtarzu 26 lipca każdego roku od 1461 do 1810 roku, kiedy w związku z kasatami napoleońskimi przeszedł na własność kapituły katedry genueńskiej. Obecnie eksponowany jest w skarbcu katedralnym w Genui ${ }^{50}$.

Na zakończenie warto zaznaczyć, że przed przewiezieniem do Genui w 1461 roku licznych przedmiotów zdobiących wcześniej łacińskie kościoły Pery do liguryjskiej metropolii ze Wschodu dotarło wiele innych dzieł sztuki. Najsłynniejszym ich przykładem jest Mandylion w genueńskim kościele San Bartolomeo degli Armeni ofiarowany przed 1383 rokiem przez cesarza Jana V Paleologa kapitanowi genueńskiemu (późniejszemu doży) Leonardowi Montaldowi ${ }^{51}$.

49 Zob. L. Tagliaferro, L“Eleusa” di Pera a Genova..., s. 7-10 (teoretycznie nie jest wykluczone, że w kościele tym znajdowały się dwie Madonny z Pery, choć wydaje się to mało prawdopodobne).

50 Zob. G. Ameri, Nuove considerazioni..., s. 169-191. Wcześniejsze propozycje datowania relikwiarza wahały się między X a początkiem XII wieku, por. I.M. Botto, Reliquiario, detto Braccio di Sant'Anna, w: Il museo del tesoro della cattedrale di Genova, a cura di C. Marcenaro, Milano 1969, tav. III; G. Ameri, Reliquiario del braccio di Sant'Anna, s. 254-257; C. Di Fabio, Bisanzio a Genova..., s. 45.

51 Spośród obszernej literatury na ten temat zob. zwłaszcza: C. Dufour Bozzo, Il "Sacro Volto" di Genova, Roma 1974 (Istituto Nazionale d'Archeologia e Storia dell'Arte. Monografie, I) oraz serię artykułów w katalogu: Mandylion. Intorno al Sacro 
Wydaje się jednak, że obok tak znanych zjawisk, jak przeniesienie do Wenecji zbioru rękopisów kardynała Bessariona, akcja ta była jednym z większych przedsięwzięć związanych $\mathrm{z}$ „importem” dzieł sztuki na teren łacińskiego Zachodu, które nastąpiły bezpośrednio po upadku stolicy Cesarstwa Wschodniego w 1453 roku.

\section{Bibliografia}

Akyürek E., Palaiologoslar Dönemi Konstantinopolisinde Dominiken Duver Resimleri. Galata Arap Camisi (San Domenico Kilisesi) Freskoları / Dominican Painting in Palaiologan Constantinople. The Frescoes of the Arap Camii (Church of S. Domenico) in Galata, w: Kariye Camii Yeniden / The Kariye Camii Reconsidered, ed. by H.A. Klein, R.G. Ousterhout, B. Pitarakis, İstanbul 2011 (İstanbul Araştırmaları Enstitüsü Yayınları / İstanbul Research Institute Publications, 14). Alizeri F., Guida artistica per la città di Genova, I, Genova 1846.

Ameri G., Nuove considerazioni sul reliquiario del braccio di S. Anna nel tesoro del Duomo di Genova, „Mitteilungen des kunsthistorischen Institutes in Florenz”, 53/2-3 (2009).

Ameri G., Reliquiario del braccio di Sant'Anna, w: Mandylion. Intorno al Sacro Volto, da Bisanzio a Genova, a cura di G. Wolf, C. Dufour Bozzo, A.R. Calderoni Masetti, Milano 2004.

Baghino P., Tra erudizione e orgoglio municipale. La questione delle opere d'arte trasportate a Genova da Pera nel 1461, w: Le "Notizie dei Professori del Disegno in Liguria" di Federigo Alizeri. Una esperienza informatica di analisi testuale, indicizzazione e consultazione interattiva, a cura di L. Kaiser, Genova 1995.

Balard M., La Romanie génoise (XII ${ }^{e}$-début du XVe siècle), Genova-Rome 1978 („Atti della Società Ligure di Storia Patria”, nuova serie 18 (92). Bibliothèque des Écoles Françaises d'Athènes et de Rome, fasc. 135).

Balletto L., I Genovesi e la conquista turca di Costantinopoli (1453). Note su Tommaso Spinola e la sua famiglia, „Acta historica et archaeologica mediaevalia” 26 (2005) (Homenatge a la Professora Dra. Carme Batlle i Gallart).

Barsanti C., Il panorama di Cristoforo Buondelmonti e le chiese latine di Costantinopoli, w: Domenicani a Costantinopoli prima e dopo l'impero ottomano. Storia,

Volto, da Bisanzio a Genova, a cura di G. Wolf, C. Dufour Bozzo, A.R. Calderoni Masetti, Milano 2004. 
immagini e documenti d'archivio, a cura di C. Monge, S. Pedone, Firenze 2017 (Biblioteca di Memorie Domenicane, 17).

Belgrano L.T., Prima serie di documenti riguardanti la colonia di Pera, „Atti della Società Ligure di Storia Patria” 13 (1877-1884).

Belgrano L.T., Seconda serie di documenti riguardanti la colonia di Pera, „Atti della Società Ligure di Storia Patria” 13 (1877-1884).

Belgrano L.T., Tavole a corredo della prima serie di documenti riguardanti la colonia di Pera, „Atti della Società Ligure di Storia Patria” 13 (1877-1884).

Botto I.M., Reliquiario, detto Braccio di Sant'Anna, w: Il museo del tesoro della cattedrale di Genova, a cura di C. Marcenaro, Milano 1969.

Brătianu G.I., Recherches sur le commerce génois dans la mer Noire au XIIIe siècle, Paris 1929.

Çetinkaya H., Arap Camii in Istanbul. Its Architecture and Frescoes, „Anatolia Antiqua. Eski Anadolu” 18 (2010).

Çetinkaya H., Byzantine Masters at the Service of the Catholic Church at Constantinople, „Porphyra” 8 (2011), no. 16 (2. Bisanzio, Venezia e l'Europa in età paleologa).

Cordaro M., Relazione di restauro del dipinto del sec. XIV: Madonna col Bambino - Genova, Galleria di Palazzo Bianco, „Bollettino dei Musei civici genovesi” 6 (1984).

Cramer J., Düll S., Baubeobachtungen an der Arap Camii in Istanbul, „Istanbuler Mitteilungen" 35 (1985).

Dal mare di Alboran a Samarcanda. Diario dell'ambasciata castigliana a Tamerlano (1403-1406), a cura di A. Spinelli, Ravenna 2004.

Dalleggio D’Alessio E., Le monastère de Sainte Marie de la Miséricorde de la Citerne de Péra ou de Saint-Benoît. Des origines a l'occupation du monastère par les Jésuites (12 mai 1427-18 novembre 1583), „Echos d'Orient” 33 (1934).

Dalleggio D’Alessio E., Le pietre sepolcrali di Arap Giami (Antica chiesa di S. Paolo a Galata), „Atti della R. Deputazione di storia patria per la Liguria” 69 (1942).

Dalleggio D’Alessio E., Recherches sur l'histoire de la Latinité de Constantinople. II: Nomenclature des églises latines de Galata, „Echos d'Orient” 25 (1926).

Dalleggio D’Alessio E., Traité entre les Génois de Galata et Mehmet II (1 $1^{\text {er }}$ juin 1453). Versions et commentaires, „Echos d'Orient” 39 (1940).

Darnault S.S., Latin Catholic Buildings in Istanbul. A Historical Perspective (18391923), Istanbul 2004.

Di Fabio C., Bisanzio a Genova fra XII e XIV secolo. Documenti e memorie d'arte, w: Genova e l'Europa mediterranea. Opere, artisti, commitenti, collezioni, a cura di P. Boccardo, C. Di Fabio, Milano 2005.

Dufour Bozzo C., Il "Sacro Volto" di Genova, Roma 1974 (Istituto Nazionale d'Archeologia e Storia dell'Arte. Monografie, I).

Düll S., Byzanz in Galata. Zur Rezeption byzantinischer Ornamente auf genuesischen Denkmälern des 14. Jahrhunderts, „Römische Historische Mitteilungen” 29 (1987). 
Düll S., Les monuments des Génois en Turquie et leurs rapports avec Byzance, w: État et colonisation au Moyen Âge et à la Renaissance, sous la dir. de M. Balard, Lyon 1989.

Düll S., Unbekannte Denkmäler der Genuesen aus Galata, II, „Istanbuler Mitteilungen" 36 (1986).

Eyice S., Testimonianze genovesi in Turchia, „Il Veltro. Rivistà della Civiltà Italiana” 23 (marzo-agosto 1979), no. 2-4 (Le relazioni tra l'Italia e la Turchia).

Girardelli P., Lo sviluppo urbano e architettonico di Galata nei documenti dell'Archivio domenicano, w: Domenicani a Costantinopoli prima e dopo l'impero ottomano. Storia, immagini e documenti d'archivio, a cura di C. Monge, S. Pedone, Firenze 2017 (Biblioteca di Memorie Domenicane, 17).

Janin R., La géographie ecclésiastique de l'empire byzantin. La siege de Constantinople et le patriarcat oecuménique, t. III: Les églises et le monastéres, Paris 1969.

Lercari A., 'Pro redemptione anime mee', w: Mercanti. Gli uomini d'affari a Genova nel medioevo, a cura di G. Olgiati, Genova 2013.

Less C., Santuario di Nostra Signora del Monte, w: Fonti per la Storia della Critica d'Arte (FOSCA), http://www.fosca.unige.it/gewiki/index.php/Santuario_di_Nostra_Signora_del_Monte (dostęp: 3.02.2018).

Loenertz R.J., Les établissement dominicains de Péra-Constantinople, „Echos d'Orient" 34 (1935).

Mandylion. Intorno al Sacro Volto, da Bisanzio a Genova, a cura di G. Wolf, C. Dufour Bozzo, A.R. Calderoni Masetti, Milano 2004.

Matteucci G., La missione francescana di Costantinopoli, vol. 1: La sua antica origine e primi secoli di storia (1217-1585), Firenze 1971 (Biblioteca di Studi Francescani, 9).

Melvani N., Dominicans in Byzantium and Byzantine Dominicans. Religious Dialog and Cultural Interaction, w: Domenicani a Costantinopoli prima e dopo l'impero ottomano. Storia, immagini e documenti d'archivio, a cura di C. Monge, S. Pedone, Firenze 2017 (Biblioteca di Memorie Domenicane, 17).

Monge C., Domenicani a Costantinopoli/Istanbul. Continuità ed evoluzione di una missione, w: Domenicani a Costantinopoli prima e dopo l'impero ottomano. Storia, immagini e documenti d'archivio, a cura di C. Monge, S. Pedone, Firenze 2017 (Biblioteca di Memorie Domenicane, 17).

Müller-Wiener W., Bildlexikon zur Topographie Istanbuls. Byzantion-Konstantinupolis-Istanbul bis zum Beginn d. 17 Jh., Tübingen 1977.

Niewöhner P., Saint Benoît in Galata. Der byzantinische Ursprungsbau, „Jahrbuch des Deutschen Archäologischen Instituts" 124 (2009).

Özden Ercan F., The Genoese of Pera in the Fifteenth Century. Draperio and Spinola Families, w: Living in the Ottoman Realm. Empire and Identity, $13^{\text {th }}$ to $20^{\text {th }}$ Centuries, ed. by C. Isom-Verhaaren, K.F. Schull, Bloomington (Ind.) 2016.

Palazzo B., L’Arap Djami ou Eglise Saint-Paul à Galata, Istanbul 1946.

Pistarino G., Chio dei Genovesi nel tempo di Cristoforo Colombo, Roma 1995. 
Polonio V., A Genova tra XIV e XV secolo. Icone e reliquie d'Oltremare, w: Intorno al Sacro Volto. Genova, Bisanzio e il Mediterraneo (secoli XI-XIV), a cura di A.R. Calderoni Masetti, C. Dufour Bozzo, G. Wolf, Venezia 2007 (Collana del Kunsthistorisches Institut in Florenz, 11).

Polonio V., Santa Maria della Misericordia della Cisterna a Pera di Costantinopoli, w: Italia Benedettina, II: Liguria monastica, Cesena 1979.

Quirini-Popławski R., "Ex partibus orientalibus translata ad hanc urbem". The Evacuation of Elements of Church Decoration from Pera to Genoa in 1461, w: Travels and Mobilities in the Middle Ages. From the Atlantic to the Black Sea, ed. by M. O’Doherty, F. Schmieder, Turnhout 2015 (International Medieval Research, vol. 21).

Quirini-Popławski R., 'Stormy Adventures' of the Relics of Pera, w: Sacrum w mieście. Wymiar religijny, kulturalny $i$ społeczny, t. 1: Średniowiecze i wczesna epoka nowożytna, red. D. Quirini-Popławska, Ł. Burkiewicz, Kraków 2016.

Salvi G., La Distruzione della Badia Genovese di Capo Faro, „Benedictina” 15 (1968).

Santamaria R., Le memorie d'arte sulle rotte dei mercant genovesi, w: Mercanti. Gli uomini d'affari a Genova nel medioevo, a cura di G. Olgiati, Genova 2013.

Sauvaget J., Notes sur la colonie génoise de Péra, „Syria. Revue d'art oriental et d'archéologie" 15 (1934).

Tagliaferro L., L“Eleusa” di Pera a Genova, „Bollettino dei Musei civici genovesi” 6 (1984).

Vigna R.A., Storia cronologica del convento di S. Maria di Castello, Genova 1889 („Atti della Società ligure di storia patria” 21).

Westphalen S., Die Dominikanerkirche der Genuesen von Pera (Arap Camii). Griechische Maler - Lateinische Auftraggeber, w: Austausch und Inspiration. Kulturkontakt als Impuls architektonischer Innovation, hrsg. von U. Wulff-Rheidt, F. Pirson, Mainz 2008 (Diskussionen zur Archäologischen Bauforschung, 9).

Westphalen S., Pittori greci nella chiesa domenicana dei Genovesi a Pera (Arap Camii). Per la genesi di una cultura figurativa levantina nel Trecento, w: Intorno al Sacro Volto. Genova, Bisanzio e il Mediterraneo (secoli XI-XIV), a cura di A.R. Calderoni Masetti, C. Dufour Bozzo, G. Wolf, Venezia 2007 (Collana del Kunsthistorisches Institut in Florenz, 11). 


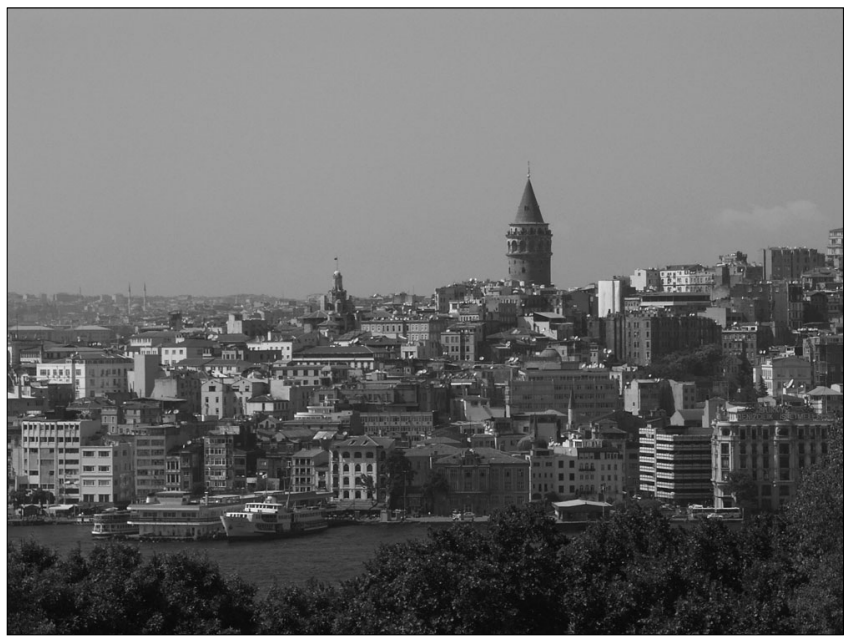

Il. 1. Stambuł, widok z pałacu Topkapı na Złoty Róg i dawną Perę (fot. Rafał Quirini-Popławski)

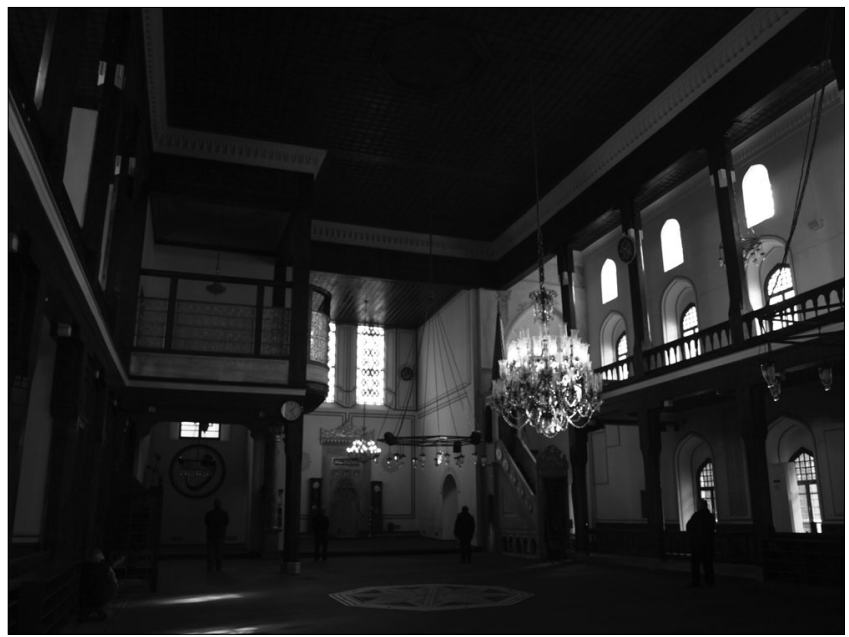

Il. 2. Stambuł, dawna Pera, podominikański kościół św. Pawła, obecnie meczet Arap Camii, zbudowany w pierwszej ćwierci XIV wieku, kilkakrotnie przebudowany i odnawiany od XVI wieku, widok wnętrza w kierunku wschodnim (fot. Rafał Quirini-Popławski) 


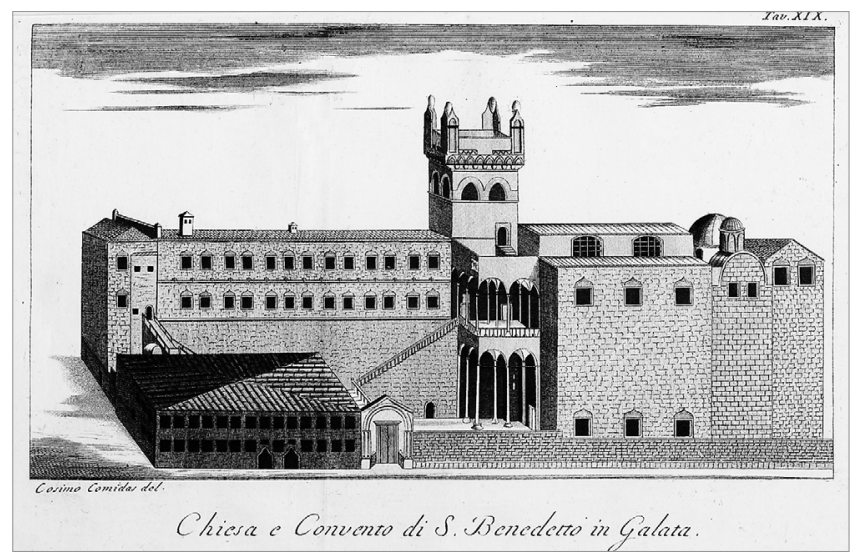

Il. 3. Stambuł, dawna Pera, kościół św. Benedykta (dawniej benedyktyński Santa Maria della Misericordia della Cisterna) z klasztorem, zbudowany w drugiej ćwierci XV wieku (?), przebudowany w XVII wieku, widok ogólny od południa (Cosimo Comidas, Descrizione Topografica dello Stato Presente di Costantinopoli arricchita di figure umiliata alla sacra real maesta di Ferdinando IV ..., Bassano 1794, tab. XIX; przedruk za: V. Polonio, Santa Maria della Misericordia..., s. 400-401, tab. VI)

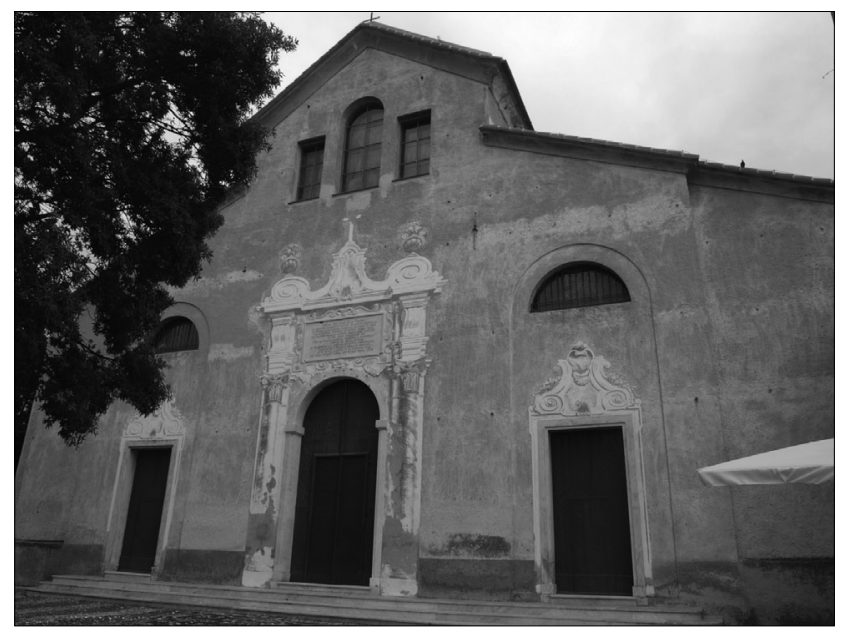

Il. 4. Genua, franciszkański kościół Santa Maria del Monte, zbudowany w latach 1440-1444, przebudowany w latach 1654-1658, fasada (fot. Rafał Quirini-Popławski) 


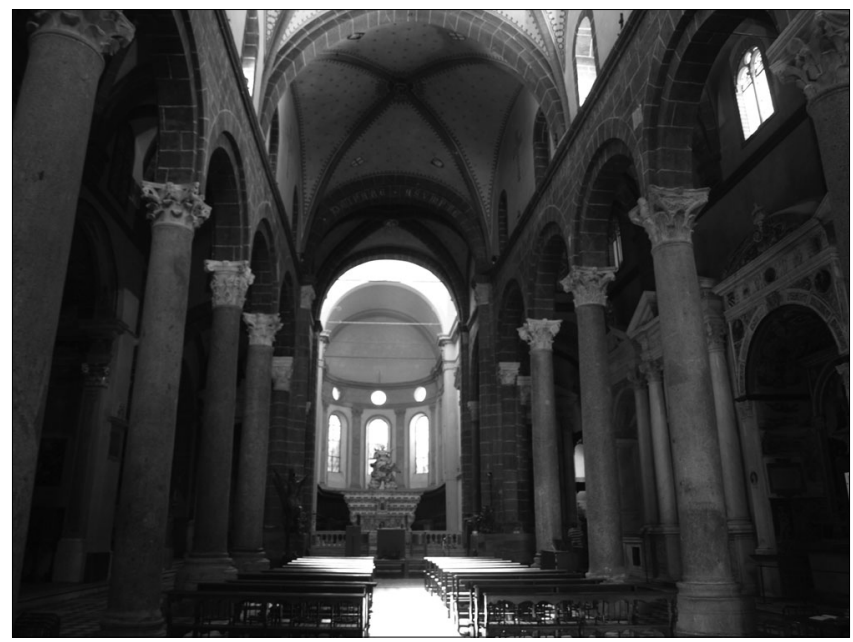

Il. 5. Genua, kościół Santa Maria di Castello, zbudowany w XII-XIII wieku, wnętrze (fot. Rafał Quirini-Popławski)

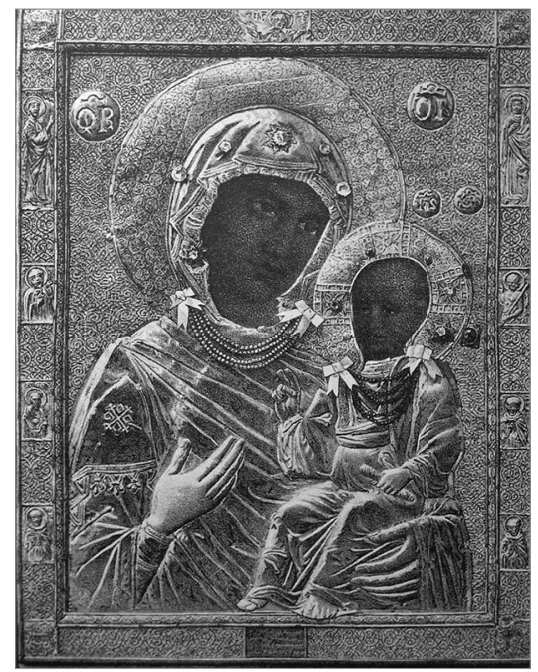

Il. 6. Madonna di Pera w metalowej sukience (koniec XIII - pierwsza ćwierć XIV wieku?) z kościoła Santa Maria di Castello w Genui, zniszczona w 1878 roku (przedruk za: L.T. Belgrano, Tavole a corredo..., tab. V) 


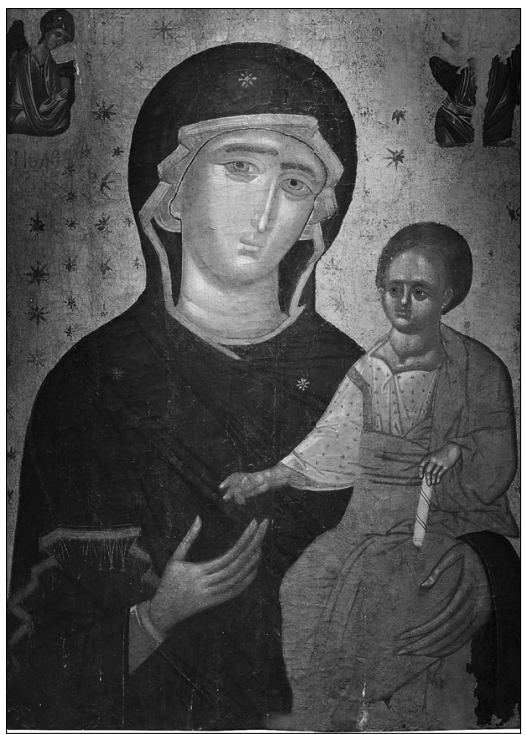

Il. 7. Madonna di Pera (XIV wiek?) z kościoła Sant'Antonio di Prè w Genui (Genua, Museo di Sant'Agostino (c) Genova, Museo di Sant’Agostino)
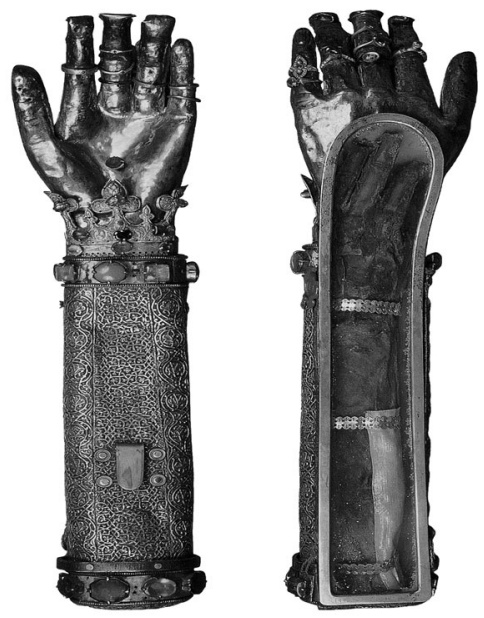

Il. 8. Relikwiarz św. Anny (początek XIV wieku?), widok z obu stron; Genua, Tesoro del Duomo (przedruk za: G. Ameri, Reliquiario del braccio di Sant’Anna, s. 254 @ Proprietà del Capitolo dei Canonici della Cattedrale di San Lorenzo, Genova) 
